\title{
The Excess Burden of Taxation in New Zealand
}

\author{
W. Erwin Diewert and Denis A. Lawrence
}

$\mathrm{N}$ ew Zealand's economy has undergone considerable reform in the last decade. Reform of the tax system has been an integral part of this process. More reliance has been placed on indirect taxes with the introduction of what is regarded as one of the most comprehensive and 'pure' goods and services taxes in the world; the income tax base has been broadened and its structure flattened; and import tariffs have been scaled down.

However, tax revenue as a proportion of gross domestic product (GDP) has continued to increase and, although it has fallen somewhat since its peak in 1989/90 and is projected to fall further, it remains very high by OECD standards. In 1990/91 taxation revenues amounted to 38.2 per cent of New Zealand's GDP, compared with 29.9 per cent in the United States and 30.8 per cent in Australia. That figure was also higher than those for Germany, the United Kingdom and Japan. All these countries' tax shares have increased over the last 25 years, but none as rapidly as New Zealand's. Furthermore, the tax shares of OECD countries tend to be very high compared to the dynamic Asian economies. For instance, South Korea, Singapore, Thailand and Indonesia all had tax shares of less than 17 per cent in 1991. In a world of increasing globalisation and capital mobility, high-tax countries will find it increasingly difficult to compete.

New Zealand's government expenditure consistently exceeded taxation revenue by a large margin in all but one of the twelve years to $1992 / 93$, by which year net public debt had risen to 55 per cent of GDP (Richardson, 1992). High levels of government spending and consequent increases in public debt imply the need for higher taxation levels in the future to cover interest and repayments on borrowings.

But what are we to make of the rapid growth in government spending over the last 20 years? Has that growth been a bad thing? Indeed, should the government be spending more? The question of the optimal size of government is a very important one. To answer it requires a balancing of the cost of additional government spending against the extra benefit it generates.

Erwin Diewert is Professor of Economics at the University of British Columbia, Vancouver. Denis Lawrence is an Assistant Director of the Bureau of Industry Economics, Canberra. The views expressed in this article do not necessarily represent those of the Bureau of Industry Economics. 
Increased government spending is often favoured by special-interest groups, and the benefits to them of such spending are usually apparent. But what is the cost of government spending to the general community? Apart from those central and local government programs that are financed by user charges or miscellaneous forms of income, government spending must be financed out of taxation or compulsory levies. It's usual to think of government spending of a dollar as costing the taxpayer a dollar; after all, a dollar going out requires a dollar coming in. However, the government's spending of a dollar costs the taxpayer more than a dollar. This is because the process of raising the dollar through taxes is itself costly.

\section{The Costs of Raising Revenue}

The costs of raising tax revenue include collection costs, compliance costs, and deadweight costs.

Collection costs. In a free society individuals arrange their affairs so as to minimise the amount of tax paid. This can be done legally (by means of tax avoidance as less preferred mechanisms are adopted to split income and substitute less heavily taxed goods for more highly taxed ones) or illegally (by means of tax evasion as income is hidden from authorities). In both cases significant resources of individuals, firms and specialist advisers are tied up in socially 'unproductive' activities. This is best summarised by Slemrod (1990: 157): 'Taxation is a system of coercively collecting revenues from individuals who will tend to resist. The coercive nature of collecting taxes implies that the resource cost of implementing a tax system is large.'

Compliance costs. Compliance costs arise from the account-keeping and formfilling that the tax system requires. A recent study by Sandford and Hasseldine (1992) found that the compliance costs of pay-as-you-earn, fringe-benefit and related taxes in New Zealand ranged up to 2 per cent of the revenue collected; those of the Goods and Services Tax exceeded 7 per cent of the revenue collected. Complying with the tax code was estimated to take up 46.5 million hours of the time of proprietors, partners, directors and other staff, and cost over NZ\$600 million in external advisers' fees as well as other miscellaneous costs. Moreover, compliance costs were found to be highly regressive in their impact. Among smaller businesses, the equivalent of 13.4 per cent of the firm's turnover was taken up in compliance costs as against only 0.03 per cent for the largest businesses.

Deadweight costs. The costs of collection and compliance are clearly large. But raising government revenue through taxes also imposes costs in a much more important but less visible way. It's not feasible to tax everything, and the tax system makes those activities that are taxed relatively more expensive than those activities that are not. Taxes thus change relative prices and, consequently, people's behaviour. Such tax-induced changes in behaviour impose an additional type of cost known as the deadweight cost or the excess burden of taxation. In a multiplicity of ways, taxes distort people's willingness to work, save, invest and take risks. These 
distortions impose costs on the economy by reallocating resources from their most productive uses to less productive ones.

Consider the taxation of labour income. Because taxation adversely affects the incentives people face, as taxes increase people tend to substitute towards leisure, work less intensively, undertake more do-it-yourself work and shift into occupations with relatively large non-pecuniary benefits. In New Zealand's case, the way many social-security benefits are provided also has a major negative impact on the incentive to work.

The total cost of a tax is thus not just what the tax raises and the collection and compliance costs. It also includes what a taxpayer would need to be paid in order to be made just as well off with the tax as without it. These deadweight costs of taxation are typically ignored. This is because they are technically difficult to estimate. Government expenditure is, at best, treated as costing no more than the dollar amount spent. The deadweight cost of tax is effectively assumed to be zero.

The size of deadweight costs is influenced by a range of factors. But it is likely to be largest when the actions of producers and consumers are highly responsive to after-tax prices, when existing marginal tax rates are high, and when savings are highly responsive to after-tax returns. International studies have typically found that the deadweight costs associated with raising taxation revenue range from a minimum of ten cents to well in excess of one dollar for each additional dollar of revenue raised. In percentage terms this corresponds to a range of 10 per cent to over 100 per cent of the additional revenue. For instance, the only study of deadweight costs in Australia (Findlay \& Jones, 1982) found a range of 23 per cent to 65 per cent, while key studies of the US have found ranges of 17 per cent to 56 per cent depending on the assumptions made. No such studies, however, have previously been undertaken in New Zealand.

Against this background, the New Zealand Business Roundtable commissioned us, through Swan Consultants (Canberra), to estimate the marginal deadweight costs of taxation in New Zealand. This article is based on our report.

\section{Estimates of the Marginal Deadweight Costs of Taxation}

The key findings of the study (Diewert \& Lawrence, 1994) are that the marginal excess burdens or deadweight costs associated with labour taxation have increased from 5 per cent to over 18 per cent in the last 20 years (Figure 1). This nearquadrupling is not accounted for solely by increases in labour tax rates, since these increased on average by only around a half — from 20 per cent of labour income to 32 per cent - over the same period.

Even though marginal deadweight costs tend to increase more rapidly than the increase in the tax rate (all else equal), much of it is accounted for by the increased flexibility and responsiveness of the New Zealand economy in recent years and increasing international capital mobility. Figure 1 shows that the rate of increase in the labour tax rate eased off after 1983, while the marginal deadweight cost of labour taxation increased rapidly after 1984 . 


\section{Figure 1}

\section{Labour tax rate and marginal deadweight cost, 1972-91}

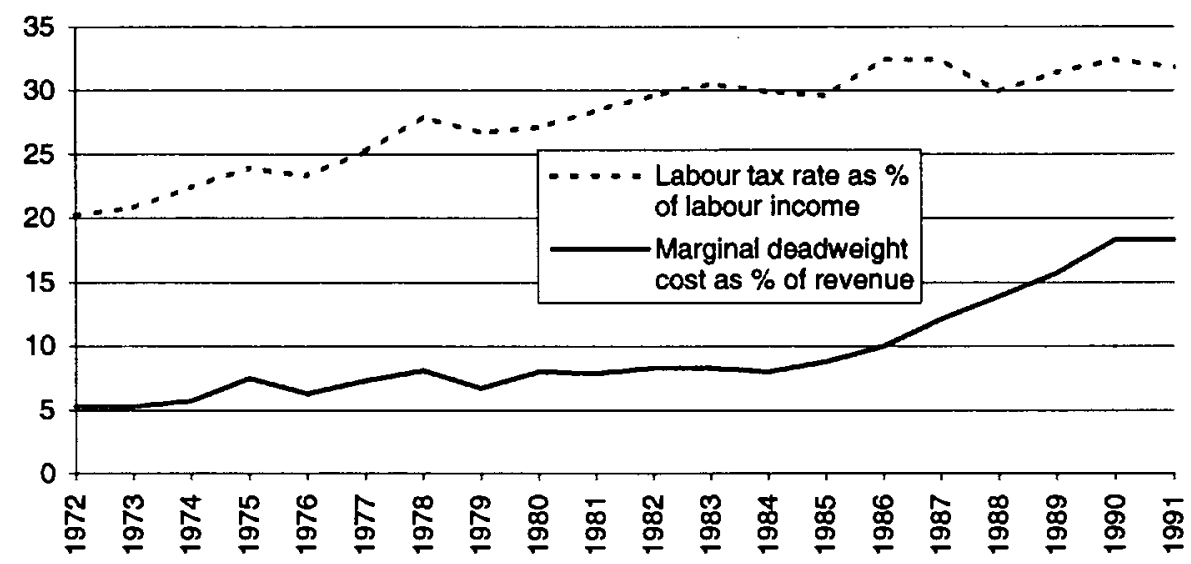

Source: Diewert \& Lawrence (1994).

Figure 2

Consumption tax rate and marginal deadweight cost, 1972-91

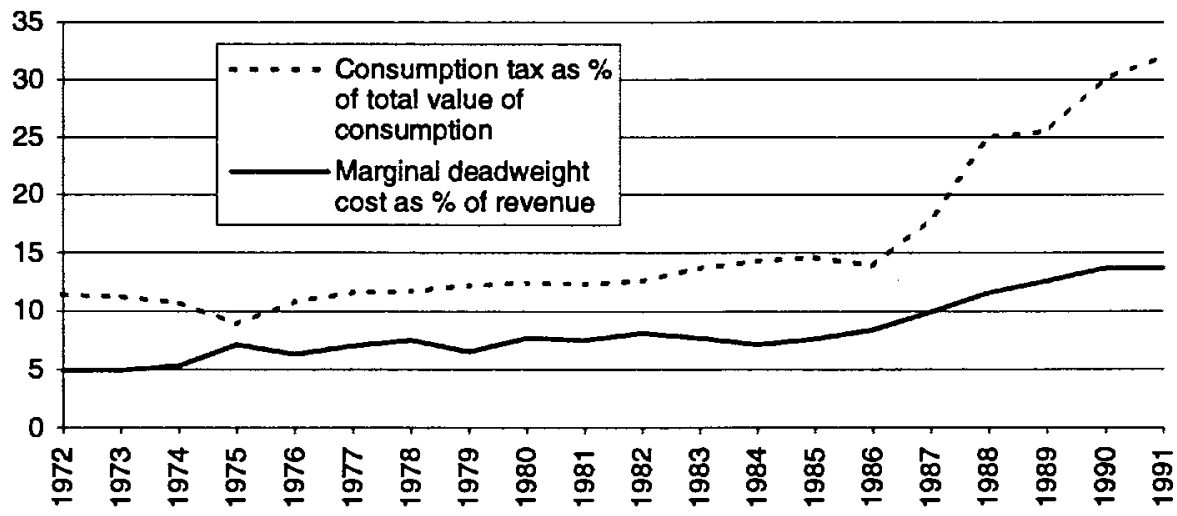

Source: Diewert \& Lawrence (1994). 
Over the last 20 years the marginal excess burden of consumption taxation (all indirect taxes other than property taxes and import duties) has increased from 5 per cent to around 14 per cent (Figure 2). This near-tripling of the consumption taxation marginal deadweight cost coincided with a near-tripling of the total consumption tax rate from around 11 per cent to 32 per cent. Most of this increase in the consumption tax rate occurred after 1986 coinciding with the introduction of the goods and services tax.

Though they fall at the lower end of the range of previous estimates of marginal deadweight costs for other countries, both of these excess burdens are quite significant. Importantly, our estimates are the first to use key parameters calculated from consistently specified statistical models of the economy being examined; previous studies have typically assumed relatively high values for these parameters. As well, our estimates are based on a rigorously specified general equilibrium model that takes account of interactions between different parts of the economy without imposing restrictions on the price responsiveness of demand and supply. Most other empirical studies have employed either a partial equilibrium model or an applied general equilibrium model that uses rather restrictive functional forms for producers' production functions and consumers' preference functions. A non-technical summary of our methodology is presented in the Appendix.

\section{Implications}

If the economic cost of labour taxation at the margin is around 18 per cent, a government project would need to return $\$ 1.18$ net of collection costs for each dollar spent on it just to cover the opportunity costs to the community of the dollar and the marginal deadweight loss. If it doesn't earn that return, society is better off not undertaking the project. That last dollar spent on defence, administration, income support, health or education means forgoing $\$ 1.18$ of benefit that would otherwise accrue to taxpayers. If the dollar of government spending were only worth a dollar to the taxpayer, the gain from reducing government spending would be 18 cents effectively an 18 per cent return.

The growth in the tax take in New Zealand has been driven by high levels of government expenditure, particularly on social services, and increasing government debt levels. While a reduction in government spending financed by reduced labour taxes would have led in 1991 to a real rate of return on this 'investment' of 18 per cent (assuming that the marginal dollar of government spending is valued at a dollar by taxpayers), a more urgent priority is likely to be a reduction in government spending accompanied by a period of unchanged taxation levels to facilitate the reduction of government debt. This would pave the way for a sustainable long-run reduction in taxation levels and associated gains to the New Zealand economy.

It is important to note that our marginal deadweight loss estimates are likely to be relatively conservative as we have not calculated the marginal excess burden of capital taxation. Other studies that have attempted to introduce dynamics and model capital accumulation decisions have shown that the marginal excess burden of capital taxation is generally higher than that of labour. This is particularly likely 
to be the case for a small economy (such as New Zealand's) trading in a world of ever increasing capital mobility.

However, our study does not imply that less government spending is always to be preferred. The optimal level of government spending is not zero. The government has an important role to play, for example in providing public goods and physical and legal infrastructure that would not be supplied - at least in desirable quantities - through private transactions. It is worth incurring the marginal deadweight costs of taxation up to the point justified by the returns to such expenditure. Our study highlights the high opportunity cost of public funds and the need to spend those funds very carefully.

\section{Policy Implications}

Despite an impressive range of reforms to its structure of taxation, New Zealand's tax share of GDP has increased rapidly over the last two decades. It is high by OECD standards and more than double those found in the dynamic Asian economies. The costs that this high level of taxation have imposed on the New Zealand economy have increased rapidly as the economy has become more flexible and integrated with the rest of the world as a result of the general deregulation and liberalisation of the economy. This should not, however, be interpreted as reflecting badly on the reforms that have flattened the tax rates and broadened the tax base. Rather, if the old structure of taxation with its disparate tax rates had been left in place while the economy was being freed up and the tax share of GDP increasing, the growth in the marginal deadweight costs of taxation would have been much higher.

Continuing reforms in New Zealand and elsewhere and ever-increasing international capital mobility will further increase the costs of high levels of taxation. Indeed, as globalisation continues, governments will face increasing pressure to be competitive in terms of its taxation system as well as the overall range of services it provides and regulations it administers. In New Zealand's case, this highlights the need for ongoing reforms and the imperative of reining in government spending levels.

Allowing government spending and levels of public indebtedness to increase unchecked would be to bequeath high levels of taxation to New Zealand's future generations. Far from being free, government expenditure comes with a high price tag and should therefore be spent well on high-yield projects or not at all. The overriding priority should be to reduce government expenditure and public-debt levels, and to pave the way for sustainable reductions in taxation levels. 


\section{References}

Diewert, W. \& D. Lawrence (1994), The Manginal Costs of Taxation in New Zealand, Swan Consultants (Canberra) Pty Ltd (report prepared for New Zealand Business Roundtable).

Findlay, C. \& R. Jones (1982), 'The Marginal Costs of Australian Income Taxation', The Economic Record 58(162): 253-62.

Richardson, R. (1992), December Economic and Fiscal Update, Minister of Finance, Wellington.

Sandford, C. \& J. Hasseldine (1992), The Compliance Costs of Business Taxation in New Zealand, Institute of Policy Studies, Wellington.

Slemrod, J. (1990), 'Optimum Taxation and Optimum Tax Systems', Joumal of Economic Perspectives 4(1): 157-78.

\section{Appendix}

\section{Summary of Methodology}

7 The critical determinant of the size of deadweight costs is the responsiveness of economic activity to changes in after-tax prices. Consequently, a major part of our study was concerned with obtaining accurate estimates of the key price elasticities for both consumers and producers. These elasticity estimates are then a key input to the small-scale general equilibrium model from which deadweight cost estimates are derived making use of duality theory.

In the case of New Zealand there is little consistent time-series data available and few econometric studies from which to obtain elasticity estimates. Since a consistent database of prices and quantities of goods and services consumed and of outputs produced and inputs used by producers for at least a 20 year period is a prerequisite for obtaining credible elasticity estimates, the construction of such a database was a major undertaking. The database covers the years 1971/72 to 1990/91.

The producer model estimated contains three outputs - motor vehicles, general consumption (excluding housing and transport) and investment, and exports and two variable inputs (imports and labour) along with two fixed inputs (capital and land). A normalised quadratic profit function was estimated for the aggregate private production sector. This provides for fully flexible modelling of production relationships between all outputs and inputs. By placing a minimum of restrictions on the production technology, this technique makes it possible to derive accurate elasticity estimates.

The consumer model estimated contains four consumption goods - motor vehicles, general consumption (excluding housing and transport), housing and lei- 
sure. A normalised quadratic expenditure function model was estimated for the representative consumer incorporating a linear spline on utility levels. This methodology again places a minimum of restrictions on the consumer's preferences and makes possible the derivation of accurate elasticity estimates. At this stage the consumer model is static. Intertemporal considerations have not been included.

The small-scale general equilibrium model equates supplies of goods from producers with the demand for them from consumers and the government. Consumer and government budget constraints are included and the balance of payments on current account and the budget deficit are specified exogenously. Producers' supplies are specified as price derivatives of the profit function in terms of producer prices, while consumer demands are specified as price derivatives of the expenditure function in terms of consumer prices.

The difference between producer prices and consumer prices represents the price wedges or distortions introduced by taxation and government subsidies. The marginal excess burden associated with changing a given tax rate is calculated as follows. Consumers' utility levels are held constant by means of transfers following a change to the tax rate. The change in overall welfare resulting from the change to the tax rate is then equal to the change in the value of the government's consumption of goods and services (what the government can purchase after it has compensated consumers to return them to their original utility level). The marginal excess burden or marginal deadweight cost is defined as minus the rate of change in welfare divided by the rate of change in revenue with respect to the given tax rate.

Marginal deadweight cost estimates are derived for four major tax categories: labour taxes, general consumption taxes, motor vehicle consumption taxes and import duties. Because the model is not dynamic (it does not have an intertemporal dimension), deadweight costs resulting from the taxation of capital cannot be calculated. Capital is instead assumed to be in fixed supply each period and investment is treated as being exogenous. 